\title{
The Refugee-Security Dilemma in Europe
}

\author{
Joanne van Selm-Thorburn
}

\begin{abstract}
Focusing on two of the institutions involved in the range of European activities on conflict prevention and displacement in the wake of the Yugoslav crisis, this article seeks to address the complex interplay of refugee protection and security enhancing strategies. The conclusion to an analysis of the mandates and expectations placed upon the OSCE's High Commissioner on National Minorities and the United Nations High Commissioner for Refugees is that the latter is at risk of abrogating its responsibilities towards refugees and potentially misinterpreting the motives of other (actual conflict prevention) organs in the international security arena and their impact (or not) on displacement. The article places this institutional and conceptual dilemma of refugee protection and security in the context of International Relations theories, and stands squarely against the view that refugees are themselves a threat to west European security.
\end{abstract}

\section{Précis}

En concentrant son attention sur deux des institutions impliquées dans le réseau des activités européennes en matière de prévention des conflits et des

Joanne van Selm-Thorburn, Ph.D., is a Lecturer in International Relations, Department of Political Science and Public Administration, Vrije Universiteit, Amsterdam, Holland.

An earlier version of this text was presented at the European Consortium for Political Research 25th Joint Sessions of Workshops (Bern 27 February-4 March 1997) in Workshop No. 24, Peaceful Change, Extended Security and the Evolving European Security Architecture under the title Refugee Protection and Conflict Prevention: The SecurityRefugee Dilemma and Institutional Structures of Prevention. My thanks to members of that panel and John Packer (Advisor to the HCNM) for their comments on that longer version. Responsibility for the contents remains the author's alone. déplacements de populations dans la mouvance de la crise yougoslave, le présent article s'efforce d'analyser l'interconnexion complexe qui s'établit entre la protection des réfugiés et les stratégies de renforcement de la sécurité. La conclusion d'une analyse des mandats et projets chapeautés par le Haut Commissaire aux Minorités Nationales de l'OSCE et le Haut Commissariat des Nations Unies aux réfugiés est que ce dernier risque purement et simplement d'abdiquer ses responsabilités envers les réfugiés et de virtuellement mécomprendre les motifs d'autres organismes (assurant de fait la prévention de conflits) dans l'arène de la sécurité internationale, ainsi que leur impact (ou absence d'impact) sur les déplacements de populations. Le présent article place ce dilemme institutionnel et conceptuel de la protection des réfugiés et de la sécurité dans le contexte des théories sur les relations internationales et s'inscrit fermement en faux contre la croyance selon laquelle les réfugiés seraient eux même une menace à la sécurité en Europe occidentale.

... if we are to break the pattern of coerced displacement, the security of States must presuppose the security of people within those States. ${ }^{1}$

Two key developments for conflict prevention and refugee protection took place when Europe was faced with the mass exodus from, and movement of displaced persons within, Bosnia-Herzegovina. The United Nations High Commissioner for Refugees (UNHCR), whose West European donors were reluctant to accept large numbers of refugees, developed policy initiatives which included a prevention role, in spite of its protection oriented mandate. The Organization for Security and Co-operation in Europe (OSCE), on the initiative of West European states, installed a new interna- tional figure as a High Commissioner on National Minorities (HCNM), with a mandate to operate in the areas of conflict prevention and early warning.

This article seeks to identify the links between minority and refugee issues in the security context, describe two of the institutions involved in the new security apparatus being established on the humanitarian level, and thus demonstrate the refugee-security dilemma in Europe at the end of the 1990s.

The issues of minorities and refugees, the rights of both groups, political decisions made on a domestic and international level concerning their acceptance and integration in societies labelled as majorities or hosts, and the whole range of interrelated issues surrounding these population groups are among the priorities on the post-Cold War security agenda. Traditional inter- and intra-state conflicts, including those with origins in minority related issues, remain the fundamental threat to European and international stability, while so-called new transnational threats such as terrorism, crime, drugs, and uncontrolled migration are perceived to have increasing importance.

The position of minorities in their state societies and the degeneration of tense situations into migration enforcing circumstances (other than generalised economic hardship as inferred in the concept of a threat of uncontrolled migration) are security concerns with a human face. These humanitarian manifestations of the security problematichave taken a key position in the building and remodelling of institutions since 1990. They are moving up the political agendas of state governments in Europe and becoming priorities of international organisations.

Within the new security architecture, encompassing Europe, the USA, Russia, and ultimately the global security construct, there should be an ur- 
gent effort made to avoid duplicitous overlap and to avoid the leaving of gaps in the security armour.

Organisations established to deal with the security scenario of the Cold War are changing to develop new strategies, included an altered notion of the need for and right to intervene in the affairs of sovereign states. There is an increasingly strongly supported notion in political and societal thought that other states and international or regional organisations have a right to intervene in states where they can: save lives; protect lives; protect themselves and other neighbouring states from the massive movements of displaced persons which could result from a war, as well as the spill-over of the violence itself.

The norm of non-intervention, based on the right of sovereignty of a state over its internal affairs, has always been challenged by the notion of humanitarian intervention. ${ }^{2}$ Exactly what humanitarian intervention is seems to be in a process of redefinition, to suit the needs of the potential interveners, and the atrocities of the state or non-state perpetrators of ill treatment to citizens in their state of origin. The three seeming justifications of the need to intervene set out above can be questioned, just as the right to intervene with justification can be questioned. ${ }^{3}$ This questioning, in conjunction with the three notions set out above would appear to result in five norms guiding the activities of international actors:

1) Discrimination of the individual or group (minority) is unjustifiable;

2) The loss of life or threat of loss of life in a conflictual situation between state and citizens is unjustifiable;

3) Forced flight is unjustifiable (but perhaps not as "bad" as loss of life);

4) The denial of protection for those displaced is unjustifiable, especially if their lives would be at risk if returned to the country of origin (but it would be better to deal with the "problem" at source); and

5) Intervention in the affairs of sovereign states is questionable (but perhaps not in all cases unjustifiable).
Complete discussion of the theoretical and philosophical problematic being presented here would require an entire book. This article is concerned with two of the institutions involved in the practical manifestations of these emerging (or in some cases entrenched) norms. The UNHCR is chiefly concerned with points 3 ) and 4) above. The OSCE HCNM is chiefly concerned with points 1) and 2). The HCNM's activities on these points are of concern and interest to UNHCR, but UNHCR's work and the points they are chiefly concerned with are not central (and in the case of point 4 almost not peripheral) to the mandate and activities of the OSCE's High Commissioner. Where both become involved, as do the states supporting (and funding) them, is on point 5.

The issues of minorities and refugees, and the security implications of their existence, position, integration, and movement are interlinked on a number of levels. Many minority populations in current European states are descendants of the migrants and refugees of the centuries gone by. ${ }^{4} \mathrm{Eth}$ nically rooted or motivated conflict between minority and majority populations can result in displacements and refugee movements. Many minorities in Eastern and Central Europe claim kinship with neighbouring states. If they feel compelled to flee their homes they would likely move to those states, potentially disturbing a fine balance between their kin majority population and its own minorities. While recognition of groups as refugees is not accorded by the 1951 Convention, the objectively provable fact of persecution due to one's membership of a social group can be a basis for the accordance of individual refugee status. Lesser statuses may also be accorded by governments recognising the basis for flight in the ethnic origins of groups of asylum seekers. Refugee influxes develop new minority populations in some states, even if sometimes only temporarily. Post-Cold War interpretation of potential conflict in Europe sees minorities at the causal end, and refugees ${ }^{5}$ as a result of the conflict process. In the 1995 General Conclusion on International Protection the Executive Committee of the High Commissioner's Program (EXCOM) states that it

condemns all forms of ethnic violence and intolerance which are among the major causes of forced displacements as well as an impediment to durable solutions to refugee problems; and appeals to States to combat intolerance, racism and xenophobia and to foster empathy and understanding through public statements, appropriate legislation and social policies, especially with regard to the special situation of refugees and asylum seekers. ${ }^{6}$

One core line of argument of this article is that the major actors in the field either depend too heavily on each other to fulfil expectations that go beyond the reality of pragmatic scope for action and of operational mandates, or by concentrating on the core necessities of fulfilling their own assigned functions ignore related issues, thereby jeopardising their own ultimate success as comprehensive action is not achieved.

A significant example of such expectations can be seen in UNHCR's 1995 State of the World's Refugees: In Search of Solutions. ${ }^{7}$ One of a limited number of special sections is devoted to the subject "Protecting Europe's minorities: preventing refugee movements." The section describes the establishment and functioning of the post of OSCE High Commissioner on National Minorities. Elements of the HCNM mandate are described, some of the first High Commissioner, Mr. Max van der Stoel's, recommendations are referred to, and his task of acting as an early warning mechanism for minority related conflicts is highlighted. With reference to this latter function, $\mathrm{UNH}$ CR's report states that it is

of particular importance, because
few of Europe's ethnic, religious and
linguisticminorities are confined to a
single state. Any form of violence,
therefore, is likely to spill across na-
tional borders and to draw in other
governments, with the risk of creat- 
ing uncontrollable regional conflicts and refugee movements. ${ }^{8}$

However, there is no reference to refugees or refugee movements in the OSCE Mandate of the High Commissioner on National Minorities (HCNM). This does not mean the work of the HCNM cannot be interpreted as having this potential impact, however, it cannot and should not be assumed that the fact of the existence of the HCNM means there will be no or fewer displacements caused by minority related conflict. In fact, by the time a conflict has gone beyond an early warning point, which it must have done if displacements occur, it is too late for the HCNM's early action. The HCNM mandate can, however, be seen to include measures aimed at increasing the potential for peace maintenance and refugee return once a conflict is clearly over. ${ }^{9}$ The HCNM can only become involved in a limited number of situations, and only with the consent and approval of an number of actors, including those directly involved. Due to the limitations placed on the scope of his work, practical, political, and constitutional, the incumbent HCNM was not involved in Russia and thus not in Chechnya in 1994 when conflict broke out there. The violent situation in Albania in 1997 is not minority related and Mr. van der Stoel, while active in Albania, thus had no role to play in signalling a potential conflict focused on political unrest and economic mismanagement.

While it is logical to assume that conflict prevention, including the prevention of conflicts between minorities and their majority compatriots, will have the spin off of preventing people's forced movement or flight, this is in no way a declared or direct element of the High Commissioner on National Minorities' work. UNHCR like many actors in world politics and international relations is in search of solutions. In its particular case, UNHCR is in search of solutions to refugee crises. Since 1992 it has turned its attention increasingly towards strategies of prevention and away from its statutory task of protection. Prevention is pro- tection, the line goes. Prevention of refugee flows is addressed by tackling the causes of forced migration and prevention of refugeehood by stopping people from crossing borders (an essential feature of the refugee condition).

UNHCR is very much at the centre of the discussion of this paper, as a long-standing organisation with a broad but specific mandate, which is facing both internal and external pressures to develop. The implication of the argument developed here with regard to this UN agency is that, drawn in by the wider security debates following the end of the Cold War and the particular crisis in Europe of former Yugoslavia, UNHCR is in danger of abdicating from its position of agency responsible for refugee protection, by seeking an alternative role as protector through prevention, and furthermore turning to others to fulfil the prevention task on its behalf.

\section{The Refugee-Security Dilemma}

The core dilemma in this discussion is that of the linkage between security and refugee flows. On the one hand a lack of security, a term used here to mean the degeneration of a tense situation into violent conflict, inevitably produces population movements, whether inside a recognised state territory or across borders-in nontechnical terms a refugee flow. A refugee flow meanwhile can cause destabilization through the fact of populations on the move, populations seeking safety first, and later work, housing, education etc., but also a destabilization on social balance in states with minorities of the same acknowledged group as the refugees, where their numerical quantity is suddenly increased, or a destabilization in terms of increased racial and xenophobic attitudes in states where sections of the population feel threatened by newcomers and outsiders, seen not as helpless people in need, but as scroungers and the thieves of limited resources. ${ }^{10}$

This security-refugee dilemma is a theoretical problematic, a result of linguistic overlap in terminology be- tween two closely related fields of practical action and academic thought and an area of practical overlap and linkage between institutions developing a complementary but distinct role in the post-Cold War global security scene.

From a security, a minority, and a refugee perspective, conflict is undesirable. Conflict is a potential cause of instability in the region. It most often provokes refugee flight (or includes forced migration as a weapon of societal destruction), it can be the result of and can become an addition to ethnic tensions in many cases, and for all these reasons it can result in calls for intervention. Furthermore, those states which could offer protection to refugees are, in the late twentieth century (as in World War II), reluctant to do so. On all levels the obvious solution seems to be to prevent conflict from breaking out in the first place. However, can or should security be rephrased as rich states with the power and strength to prevent conflicts protecting themselves from refugee influxes or in situ protection requirements? And if such a rephrasing would be ethically justifiable in itself, would or should states have any greater political will to step in to potential conflicts than has been the case with each call for humanitarian intervention to date?

The activities of the HCNM and those of other third party diplomats and mediators not examined in depth here are all measures of conflict prevention. However, conflict and human rights abuses, while they are not unavoidable, are not eradicable as yet either. People are still forced to flee. Indeed, because the security apparatus of the post-Cold War era is still in a state of transition, and because the spread of global power and interests remains unsettled, more massive refugee producing situations are taking place in the mid 1990s than took place in the previous four decades combined. Protectors of the refugees are absolutely essential.

Refugees are considered by some to be a threat to sovereignty and security. 
In the era of the "global citizen," with ethical approaches to political activities and decision-making increasing in popularity with the people, the state of flux in realist inter-state relations means that the normative standpoint taken is often that of the right of the citizen and not of the human being. Why should foreigners have the rights to take "our" jobs and welfare benefits just because their own people fight? Actions such as Proposition 187 in California or the withdrawal of housing and benefits from those who do not declare their desire to seek asylum immediately on entry to the United Kingdom do not emerge out of a political vacuum in which no one will vote for those propagating the stance. The politicians involved in formulating these policies must sense that a proportion of the population whose votes they seek desire these xenophobic stances.

However, the security issue in refugeehood comes not from a conspiracy by the world's poor to invade the rich countries and take all the jobs and benefits. The security problem is earlier-it is the breakdown in security which forces refugees to flee. Security used to mean protecting territory from armed invasion and occupation or nuclear attack. Refugees have moved on to the security agenda as a threat. This perception is a misjudged interpretation of the refugee position in regional and global security. Realising that persecution of minorities was one root of the conflict in Bosnia Herzegovina, and that this story could repeat itself in other central and Eastern European states, the OSCE participating states agreed to create a High Commissioner on National Minorities as a conflict prevention tool and early warning mechanism. Refugee protectors have seemingly jumped on this development as a step forward in their cause. In some ways there is a movement forward, but without intention or drive.

\section{HCNM Mandate}

The OSCE High Commissioner on National Minorities is, according to the mandate, an instrument of conflict pre- vention at the earliest possible stage. The HCNM is to provide "early warning" and, as appropriate, "early action," in regard to tensions involving national minority issues which have not yet developed beyond an early warning stage, but, in the judgement of the High Commissioner, have the potential to develop into a conflict within the OSCE area, affecting peace, stability or relations between participating states. This means that HCNM action is restricted to pre-conflict situations, under circumstances in which tensions between majorities (often governments) and minorities can be expected or anticipated. The High Commissioner can issue an early warning if he or she concludes that there is a prima facie risk of potential conflict as described in the previous sentence.

This decision is to be based on information the HCNM may collect and receive regarding national minority issues from a variety of sources including the media, NGOs, governments, religious groups and others, provided they do not practice or publicly condone terrorism. Parties directly involved may communicate their concerns and information on the situation in writing to the HCNM directly, giving their full name and address, providing their information can be readily substantiated, and is about the situation of the previous twelve months maximum. The HCNM's early warning would be issued to the Chairman-in-Office and then communicated to the Senior Council (previously Council of Senior Officials). The Senior Council may then trigger the "Emergency Mechanism" as set out in Annex 2 of the Summary Conclusions of the Berlin Meeting of the Council. The HCNM must give an explanation of the reasons for the warning to the Council. In the first four years of activity no early warning was issued by the HCNM.

Early action meanwhile involves further contacts and closer consultations with the parties involved, most usually via visits to the state(s) concerned.
The HCNM is part of the OSCE's "touchy-feely" participation as a thirdparty observer, facilitating, monitoring, fact-finding, and gently mediating rather than enforcing or muscling in to a peace-making role. ${ }^{11}$ The incumbent HCNM has used quiet diplomacy to make advances in peaceful relations between governments and minorities in the thirteen states in which he has been active. ${ }^{12} \mathrm{He}$ and his team of advisors use the media and personal contacts with relevant organisations and officials to keep themselves informed of developments in the political situations in the countries involved. The High Commissioner and his appropriate advisor make visits to states on a regular basis. Usually, the calmer the situation the less frequent the visits, although contact is maintained. He meets with government officials and representatives of minority groups, and issues a letter of recommendation to the government following his visit. A written response is usually made to this letter, and at that point it is usually approved for public release by the Parliamentary Assembly of the OSCE. The High Commissioner has favoured the establishment of Roundtables as dialogue mechanisms, and this method of discussion has been used with most particular effect in relations between the Ukrainian authorities and representatives of Crimea in attempting to resolve constitutional issues. Other examples of this Roundtable dialogue are to be found in the Baltic states. The High Commissioner is also active in diplomatic efforts to resolve sticking points in the conclusion of bilateral treaties, such as those between Hungary and Slovakia and Hungary and Romania.

\section{UNHCR Statute}

The United Nations General Assembly adopted the Statute of the Office of the United Nations High Commissioner for Refugees in Resolution 428 (V) of 14 December 1950. The UN High Commissioner for Refugees is to

assume the function of providing international protection, under the auspices of the United Nations, to 
refugees falling within the scope of the present Statute, and of seeking permanent solutions for the problems of refugees by assisting Governments and, subject to the approval of the Governments concerned, private organizations to facilitate the voluntary repatriation of such refugees, or their assimilation within new national communities. ${ }^{13}$

The part of this mandate where prevention activities could be seen to fall is in the search for permanent solutions for the problems of refugees. What could be more permanent as a solution than not becoming a refugee in the first place? However, the mandate presupposes that while the agency exists its activity will be to protect those who have already become refugees, finding solutions to the situation in which they find themselves.

The UNHCR's work is to be of a nonpolitical character, i.e. to be impartial in conflict situations, protecting all refugees regardless of their affiliations (except for war criminals) and to help all sides. It is also to be humanitarian and social and to relate to groups or categories of refugees. ${ }^{14}$ This distinguishes international protection from the individualised character of state recognition of refugeehood and accordance of refugee status following the guide of the 1951 Convention Relating to the Status of Refugees and 1967 New York Protocol. The definitional scope of those to be protected by the agency however is individualised ("Any person who ...") and is very similar to the definitional clause of the 1951 Convention, although the addition of fearing persecution due to membership of a social group was added to the later document. ${ }^{15}$

The High Commissioner for Refugees is, according to the Statute, to provide protection for refugees by promoting international conventions for the protection of refugees, supervising their application and suggesting amendments; promoting measures to improve the situation of refugees and to reduce the numbers requiring protection; assisting voluntary repatriation or assimilation; promoting admission and the transfer of assets needed for resettlement; obtaining complete information on numbers of refugees and domestic laws and regulations concerning them; maintaining contact with governments, NGOs and private organisations, and facilitating work of these latter concerned with the welfare of refugees. ${ }^{16}$

The work of the High Commissioner is to be carried out with reference and responsibility to the General Assembly. The General Assembly has on a number of occasions broadened the mandate of the UNHCR, for example by requesting "good offices" in a number of refugee producing situations in Asia and Africa in the 1970s and more recently by assigning it the role of lead agency in the relief efforts in former Yugoslavia. The effect of this has been to make UNHCR the agency with de facto responsibility for the protection and relief of internally displaced persons as well as refugees, although no such function officially exists.

From the beginning of the refugee crisis in former Yugoslavia, the UNHCR issued calls for adaptations in protection regulations and policies, as European states showed reluctance to grant status to the large groups of former Yugoslavs and Bosnians requesting asylum in their territories. ${ }^{17}$ While not actually a suggestion for a convention or amendment of existing refugee conventions, these adaptations would clearly be protective tasks or duties of the UNHCR. However, it has also turned its attention to the prevention of refugee flows, both by participating in thecreation of "safe areas" within countries of origin (thereby allowing potential host governments to claim a safe flight alternative or to expect less exits) and by encouraging the development of root cause approaches-preventing displacements if possible. ${ }^{18}$ This participation potentially falls within the scope of "reduc[ing] the number requiring protection," if successful, but it should not be allowed to compromise the essence of protection.

\section{Links between the Two Institutions}

On a practical level the closest working link between the OSCE and UNHCR has been cooperation on the CIS Conference held in May 1996 to discuss the massive displacements and management of flows of refugees and internally displaced persons in the countries of the former Soviet Union. The organisation of this conference was a cooperative effort between UNHCR, the International Organisation for Migration, and the OSCE. The OSCE's input was channelled via the Office for Democratic Institutions and Human Rights (ODIHR). The High Commissioner on NationalMinorities' role was very minimal, although NGOs, scholars and perhaps cooperating organisations and states may have expected more. It was, however, an example of the type of situation in which a close reading of the HCNM mandate and following of his activities would indicate that, as a political figure, his involvement could influence his own effectiveness and the outcome of proceedings. After all, while the HCNM is not active in Russia, Russians form minorities in many of the states of the Baltic and Central Asian regions where he is involved. Russia's outspoken stance on the subject of its nationals and Russian speaking groups in the "near abroad" is well known. Pressure concerning the granting of citizenship or some sort of status to migrants from these groups would be politically very difficult for a person in the political position of the OSCE HCNM. With conflict prevention as a major task, a HCNM could not put him or herself in the position of advocating a stance which could put negotiating partners against him or her. The HCNM is not even a High Commissioner for National Minorities, but on National Minorities-not advocating the position of minorities or acting as an ombudsman on their behalf but dealing in matters which affect the relations between minority groups and governments, and trying to facilitate compromise and a satisfactory relationship for all. 
The UNHCR highlights prevention as protection, but it cannot act on its preventive desires as such activity does not lie within its mandate or capabilities. The HCNM acts to prevent conflicts or give early warning of their potential eruption, and his activities may have the side-effect or preventing some people from becoming refugees, however this is not a primary purpose of his work or mandate.

\section{Conclusion: Institutional and Political Needs}

Do we need a security organisation which strives to prevent refugee crises? At the root of much talk of prevention of refugeehood is the lack of willingness to effectively protect those forced to flee by conflict, either as a host state or by intervening to protect the displaced in situ. The humane goal in interventionist strategies often seems to be protecting the lives of the interveners' armed forces, and protecting one's own citizens from the impact of a lack of security caused by the failure of other states to protect their citizens. States see it as being in their interest not to receive large numbers of asylum seekers. For reasons of self interest they also decide whether or not it is appropriate for them to intervene in a "foreign war." Those same states are the providers of mandates and funds for the organisations which administratively and operationally deal with all the issues involved in this security debate. States need to guide the organisations which serve them and in which they cooperate to coordinate and cover all aspects of the issues and to clearly stick to the most appropriate mandate. The UNHCR would do a disservice to those who must become refugees if they let a protection emphasis slip and focus on prevention. Prevention cannot always succeed, someone has to protect those it fails.

The overlap between the mandates of the two offices discussed here is minimal. The links between them come in the late twentieth century understanding of the security-minorityrefugee-security continuum. The UNHCR cannot and should not rely on the HCNM to prevent refugee crises in Europe. The UNHCR also needs to search deeply into the question of to what extent prevention is protection. Its mandate has always been to give international protection to those in a refugee-like situation. Its role in the twenty-first century must be to protect those whose forced displacement was not preventable, and support others in prevention activities. Above all, it must lend a moral voice to the debate on behalf of people who through no fault of their own become refugees. UNHCR should expect other (security) organisations to listen to its calls for more action to protect people from displacement, particularly if states continue in their reluctance to provide traditional asylum.

From an idealist perspective there should be a layering of cooperating organisations linking military, diplomatic and political efforts to ensure security by preventing or resolving conflictual situations, establishing a global human rights regime and protecting those who become the victims of violence and human rights abuses. Within this pluralist view the major issues are shifting. Protecting territory and citizens of richer states from an ideological foe is no longer the priority. However, protecting territory and citizens of the rich world from refugee invasion is a mistaken effort at reprioritising. Protecting the rights of all humans, allowing all to live in peace and security should be the goal of a global society based on the normative values espoused during the last fifty years. The major protectors of rights and security are still states. The end of the Cold War has shifted the balance from a realist perspective- that much is undebatable. Where the balance of power now lies, what sort of power is most relevant and which states hold it, and indeed whether states are the sole actors in international relations, are all open question. States need to cooperate on the human issues paramount at the end of the twentieth century, using the organisations they have established to expand in terms of membership and competence to cover all aspects of security, migration, and ethnic relations. They also need to realise that minorities and refugees are not necessarily a threat to state power, but could be the key to showing the extent of the power of humanity.

\section{Notes}

1. UN doc. A/AC.96/860, The Report of the Forty-sixth Session of the Executive Committee of the High Commissioner's Programme, 23 October 1995, Annex: Opening Statement by the High Commissioner, Monday $16 / 10 / 95$.

2. See M. Akehurst, "Humanitarian Intervention," and Hoffman, S., "The problem of Intervention," both in Intervention in World Politics, edited by H. Bull (Oxford: Clarendon Press, 1984).

3. See M. Walzer, Just and Unjust Wars (New York: BasicBooks, 1992, 2nd ed.).

4. For theoretical approaches to the explanation of minority formation through migration see S. Castles and M. J. Millar, The Age of Migration: International Population movements in the Modern World (London: Macmillan, 1993), particularly Chapter 2, "The Migratory Process and the Formation of Ethnic Minorities."

5. The term refugees is used here in its broader and more common sense and not restricted to the definition contained in Article 1 A paragraph 2 of the 1951 Convention Relating to the Status of Refugees. This Convention defines a refugee as any person who

as a result of events occurring before 1 January 1951 and owing to wellfounded fear of being persecuted for reasons of race, religion, nationality, membership of a particular social group or political opinion is outside the country of his nationality and is unable or, owing to such fear, is unwilling to avail himself of the protection of that country; or who, not having a nationality and being outside the country of his former habitual residence as a result of such events, is unable or, owing to such fear, is unwilling to return to it.

6. UN doc. A/AC.96/860, The Report of the Forty-sixth Session of the Executive Committee of the High Commissioner's Programme, 23 October 1995, paragraph (h). In paragraph (i) EXCOM calls on UNHCR to support States and cooperate with the UN High Commissioner for Human Rights on the development of an effective human rights regime.

7. UNHCR, State of the World's Refugees: In Search of Solutions (Oxford: Oxford University Press, 1995). 
8. Ibid., 80.

9. The HCNM's involvement in Croatia since 1996 is proof of this.

10. On the so-called new xenophobia, or reemergence of this phenomenon, see New Xenophobia in Europe, edited by B. Baumgartl and A. Favell (The Hague: Kluwer Law International, 1995).

11. See Janie Leatherman, “The CSCE's (Im)Possibilities for Preventive Diplomacy in the Context of Ethnic Conflict," International Journal on Group Rights 2, no.1 (1994): 35-54.

12. For a broad description of how the HCNM becomes involved in countries, and his activities in the thirteen states in which he has been active see The Role of the High Commissioner on National Minorities in OSCE Conflict Prevention, (The Hague: Foundation on Inter-Ethnic Relations, 1997).

13. Statute of the Office of the United Nations High Commissioner for Refugees, UN General Assembly Resolution 428 (V), 14 December 1950, Annex 1, Chapter I, 1.

14. Ibid., Chapter I, 2.

15. Ibid., Chapter II, Aii, Convention Relating to the Status of Refugees, 1951, Article 1a.
16. Ibid., Chapter II, 8.

17. See Joanne Thorburn, "Transcending Boundaries: temporary protection and burden-sharing in Europe," International Journal of Refugee Law 7, no. 3, 1995.

18. See Joanne Thorburn, "Root Cause Approaches to Forced Migration," Journal of Refugee Studies 9, no. 2, 1996.

\section{Bibliography}

Baumgartl, B., and A. Favell, eds. 1995. New Xenophobia in Europe. The Hague: Kluwer Law International.

Bull, H., ed. 1984. Intervention in World Politics. Oxford: Clarendon Press.

Castles, S., and M. J. Millar. 1993. The Age of Migration: International Population movements in the Modern World. Chapter 2 The Migratory Process and the Formation of Ethnic Minorities. London: Macmillan.

Leatherman, Janie. 1994. “The CSCE's (im)Possibilities for Preventive Diplomacy in the Context of Ethnic Conflict." International Journal on Group Rights 2, no. 1, 35-54

Statute of the Office of the United Nations High Commissioner for Refugees. UN General
Assembly Resolution 428 (V), 14 December 1950, Annex 1.

Thorburn, Joanne. 1995. "Transcending Boundaries: Temporary Protection and Burden-sharing in Europe." International Journal of Refugee Law 7, no. 3.

- 1996. "Root Cause Approaches to Forced Migration: Part of a Comprehensive Strategy? A European Perspective." Journal of Refugee Studies 9, no. 2.

United Nations. 1995. The Report of the Fortysixth Session of the Executive Committee of the High Commissioner's Programme. UN doc. A/AC.96/860, 23 October.

-1996. Report of the Forty Seventh Session of the Executive Committee of the High Commissioner's Programme. UN doc. A/ AC.96/878, 11 October.

UNHCR. 1995. State of the World's Refugees: In Search of Solutions. Oxford, UK: Oxford University Press.

Walzer, M.1992. Just and Unjust Wars. 2nd ed. New York: BasicBooks.

The Role of the High Commissioner on National Minorities in OSCE Conflict Prevention. The Hague: Foundation on Inter-Ethnic Relations, 1997. $\square$

\section{Asylum: A Moral Dilemma \\ By W. Gunther Plaut}

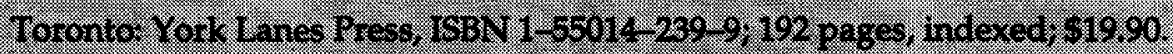

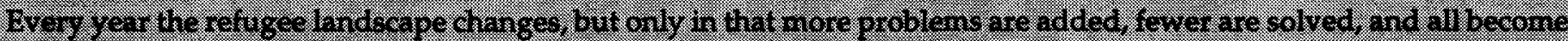
consteruty more ungent. Fuelled by the explosion of the would s population, the quest for asylum is one of the most

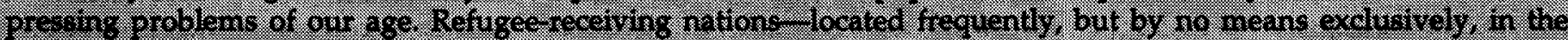

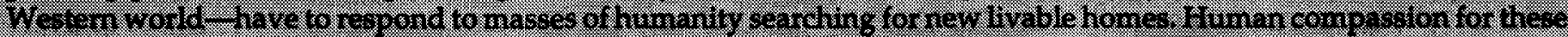

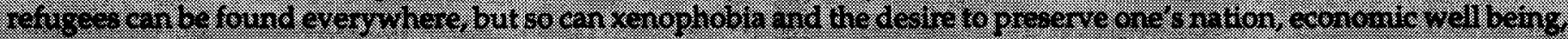

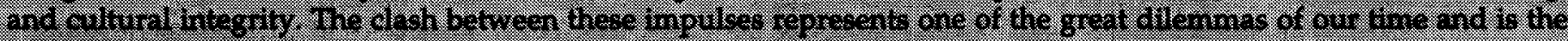

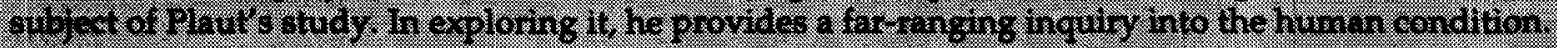

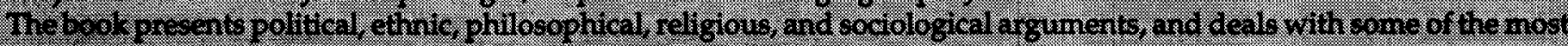

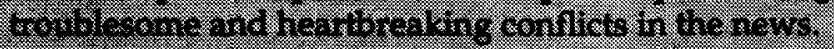

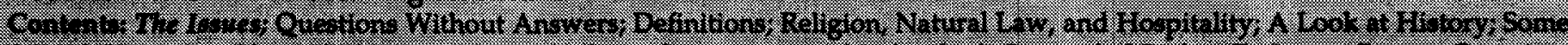

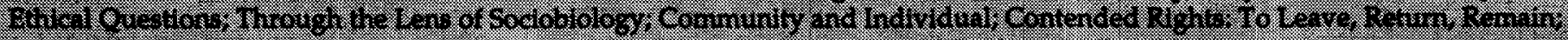

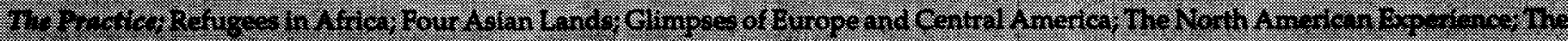
som

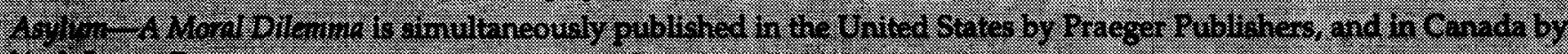

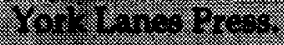

